\title{
Transforming Abandoned Rail Corridors into Multi-purpose Trails: Applying a Spatial Hedonic Approach to Estimating the Economic Benefits of the Little Miami Scenic Trail in Cincinnati, Ohio, USA
}

\author{
Wen Zhang1 (i) $\cdot$ Seunghoon $\mathrm{Oh}^{1} \cdot$ Rainer vom $\mathrm{Hofe}^{1}$
}

Received: 1 November 2018/Revised: 1 December 2018/Accepted: 6 December 2018/Published online: 22 December 2018

(C) The Author(s) 2018

\begin{abstract}
This research assesses the appreciation in residential property values in connection with proximity to the Little Miami Scenic Trail, a multi-purpose biking, hiking, and jogging trail built along an abandoned railroad corridor near Cincinnati, Ohio, USA. Applying two spatial hedonic frameworks, the spatial lag of X (SLX) model and the spatial Durbin error model, we conclude that proximity to trail entrances had significant impacts on property values for both, Euclidean and network distance measures. Specifically, the SLX results indicate that decreasing the distance to the closest trail entrance by one foot (meter) increases a house's property value by US\$0.92 (US\$3.02) when using network distances.
\end{abstract}

Keywords Abandoned railroad corridor - Multi-purpose trails $\cdot$ Spatial hedonic price models $\cdot$ Economic benefits

\section{Introduction}

In the USA, countless miles of under-utilized and abandoned railroad corridors within urban and suburban areas occupy valuable land resources, thus negatively affecting nearby communities both economically and aesthetically. Transforming those corridors into beneficial public assets has become a challenge for urban planning practitioners and researchers. One potential answer to reusing these out-

Wen Zhang

zhang2w4@mail.uc.edu

1 School of Planning, University of Cincinnati, Cincinnati, OH 45221-0016, USA

Communicated by Christopher Auffrey, Haishan Xia, and Chun Zhang. of-service railway lines is to convert them into multi-purpose trails, also referred to as rail trails [1]. Such rail trails are recreational amenities that benefit both the natural environment and nearby residents. Rail trails are characterized as being separate from the street networks, with low slopes, connection to the communities via trail heads, and passing through varying landscapes [2]. These characteristics make rail trails very desirable for safe non-auto-oriented connectivity and recreation and provide a feasible option for those cities with redundant, obsolete, and abandoned rail corridors [3].

In China, multi-purpose trails are receiving increased attention from urban planners. The Study of General Planning and Pilot Schemes for Recreational Trail Systems in Beijing [4] will, if implemented, provide for $3000 \mathrm{~km}$ of multi-purpose trails across the city's 16 counties and districts. The planned trail system intends to connect natural areas and historic sites, responding to resident's growing demand for outdoor recreational space, while improving their quality of life and integrating regional tourism resources [5].

In the USA, there have been a few recent studies of trail systems emphasizing the importance and benefits of multipurpose trail systems in Chinese and US cities [6]. These studies find that trail development linked with carefully planned urban renewal programs allows linear open space development in the urban core while complementing traffic calming systems, enhancing pedestrian safety and experience [7]. Further, local and regional planners should explore alternative development approaches for multipurpose trails by linking riverfront developments, street renovations, and revitalization of obsolete rail corridors [8].

While the environmental and aesthetic benefits of wellplanned and implemented urban rail-to-trail conversions 
are generally understood, their economic and fiscal impacts are less well studied by urban planners and policymakers. This research aims at filling this knowledge gap. Using the Little Miami Scenic Trail as a case study, this research estimates the impacts of this rail trail on market values of nearby single-family residential properties. Using a spatial hedonic pricing model, both direct effects (a property's own attributes) and indirect spillovers (properties affecting each other) are taken into consideration. This framework allows researchers to estimate the change in a residential property's value based on its proximity to the Little Miami Scenic Trail. Such an approach can provide valuable information to planners and transportation policymakers in both China and the USA.

As indicated in Fig. 1, the section of the Little Miami Scenic Trail (Fig. 1) included in our study is located in the Eastern part of Hamilton County, Ohio, the home county of the City of Cincinnati. This multi-purpose trail was constructed for biking, jogging, and hiking [9] in the corridor of the former Little Miami Railroad (LMR). Constructed in the mid-1800s, the LMR was one of the early rail lines operating in Ohio. Prior to that time, waterways were the primary means of transportation from the mid-west to the east coast. The LMR was established to connect Lake Erie with Ohio River, giving it a north-south orientation. As railroads expanded and their technology improved, connections to Cincinnati directly from east proved to be faster and more efficient, relegating the LMR to servicing smaller markets. After a series of changes in ownership, the railroad went out of business and its rail corridor was abandoned in the 1970s. The Ohio Department of Natural Resources, local governments, and the Ohio Department of Transportation were able to acquire portions of the corridor and to construct of what has become the Little Miami Scenic Trail as early as the 1980s [10].

The Little Miami Scenic Trail extends approximately 78 miles $(125.53 \mathrm{~km})$ through Clark, Clermont, Greene, Hamilton, and Warren counties in Ohio. The trail is the third longest paved trail in the USA with more than 700,000 users annually and is an important recreational asset for the Greater Cincinnati metropolitan area. This study focuses on the 12 -mile $(19.31 \mathrm{~km})$ portion of the trail located within Hamilton County. This specific section in Hamilton County has as many as 23 entry points, i.e., trail heads, where people can enter the trail. The trail is paved with asphalt and concrete, and offers a pleasant natural environment and scenery as well as access to several cultural attractions. On study counted over 7000 users over two days, suggesting the popularity of this portion of the

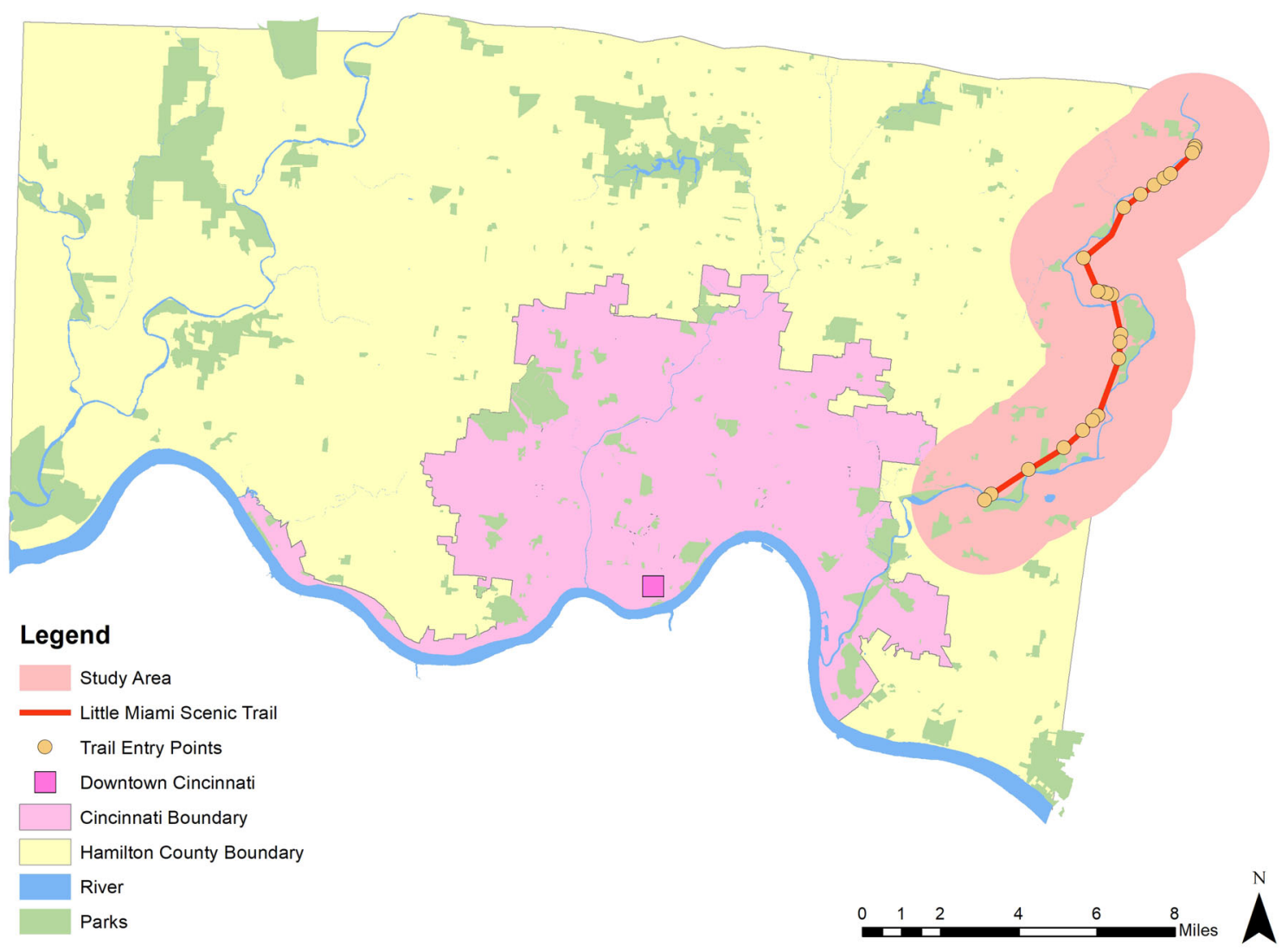

Fig. 1 Location of the study area 
trail and supported the potential implications of this study [9].

The next section reviews the relevant literature. Section 3 describes the data and presents some summary statistics. Section 4 discusses the methodology and introduces the spatial lag of $X$ and spatial Durbin error models used to identify the impact the Little Miami Scenic Trail has on residential property prices. Section 5 discusses the results of the estimation, and Sect. 6 presents the concluding remarks.

\section{Literature}

Urban amenities, such as desirable climate, environmental quality, and recreation and entertainment opportunities, affect people's quality of life. Amenity-rich cities have grown faster than cities that lack amenities. Sorens [11], in a study on interstate migration, found that expected income differentials and amenities play an important role when people relocate. Individuals and households demand more varieties in urban amenities. Glaeser et al. [12] in an earlier empirical study already revealed a strong positive relationship between the amenity value and future population growth and concluded that amenities attract population (pp. 13). Glaeser et al. [12] in their study identified four critical urban amenities, namely (1) the presence of a rich variety of services and consumer goods, (2) aesthetics and physical setting, (3) good public services, and (4) speed, or the ease with which individuals can move around.

In the meantime, a rich body of literature of hedonic pricing studies emerged that evaluate more closely on how urban amenities influence housing prices. Based on the theoretical framework by Lancaster [13] and Rosen [14], a large number of these studies investigate the premiums homebuyers are willing to pay to be in close proximity to bodies of waters (ocean, lakes, rivers, etc.), urban greenspaces (forests, parks, tree coverage, etc.), nature reserves and open spaces, and transportation facilities (highway access, streetcar, bike trails, etc.) for instance. The list of potential applications for the hedonic framework is sheer endless, but many have in common that the demand for housing can be associated with nearby amenities. In addition, the existence of spatial heterogeneity implies that the impact of those amenities is location-specific and as such varies depending on locations [15-17].

The list of public goods that potential home buyers take into account when looking for a new home is as long as the list of hedonic studies. Besides structural housing characteristics, hedonic studies usually include neighborhood and locational characteristics, such as the quality of the school district $[18,19]$, the availability of public transportation infrastructure $[20,21]$, and the distances to lakes and/or rivers [22, 23]. Other studies include crime [24, 25] and the close proximity to brownfields [26, 27]. Of particular interest for the presented research are recreational and environmental amenities, such as parks [28, 29], bike trails $[9,30]$, greenbelts, forests $[15,31]$, and open spaces $[16,32]$.

The discussion of the positive externalities of greenways and urban parks has gained momentum in recent years among planning and public policy scholars. Particularly when public funding is scarce, the economic impacts of spending public funds on urban amenities, such as parks and bike trails, become an important component of the public policy process. The question then often arises on whether or not existing and newly planned parks and trails positively affect residential property values and as such influence the local tax base by means of the property tax. Generally, the presumption is that parks and trails have a positive effect on housing prices [9], but the relevant literature also shows that these amenities can have either no effect or even a negative impact on property values $[16,33,34]$. These differences in outcomes depend widely on the heterogeneity that can be found in the types of facilities and the neighborhood characteristics [17, 35-37].

An earlier study of the Little Miami Scenic Bike Traila rail-to-trail conversion-by Parent and vom Hofe [9], which used spatial econometric estimation techniques, found a considerable positive effect of the trail on singlefamily residential property values within a 10,000 feet (3048 m) distance from the closest trail entrance. Kashian et al. [30] found in Muskego, Wisconsin, that an abandoned railroad corridor depreciates home values. But when turning the abandoned rail corridor into a bike trail, home values appreciate with decreasing distances to the trail. Kang and Cervero [38] studied a freeway-to-greenway conversion using a multi-level hedonic analysis, and found that this newly built urban greenway has land value premiums for either residential as well as commercial properties. The authors further highlight that both land uses positively impact commercial property values, but that the impact from the greenway is notably higher. Krizek [33] compared on-street bicycle lanes, off-street bicycle trails (multi-purpose paths including rail trails), and roadside bicycle trail within a non-spatial hedonic framework. Using distance measures for each home to the nearest trails, Krizek found that off-street bicycle trails appreciate home values in the city, while roadside bicycle trails have a negative impact on house values. He further concludes that suburban residents do not value bicycle facilities to the same extent as city residents.

Parent and vom Hofe [9] considered a trail impact of up to 10,000 feet $(3048 \mathrm{~m})$ from the nearest trail head. Of much interest for the presented research is also a study by Lindsey et al. [35], who argued that many trail users further 
than $1 / 2$ mile away from the trail are more likely to drive to the trail. Lindsey et al. showed that within $1 / 2$ mile to the Monon Trail, a converted rail trail in Indianapolis, IN, up to $14 \%$ of sales prices are attributable to the trail. Time plays a crucial role in the study by Ohler and Blanco [39]. While a bike trail in Bloomington, IL, initially had a negative impact on home values, over time the effect of the trail on home values turned positive. In addition, networked bike trails have greater effects than non-networked trails. Welch et al. [37] estimated the joint impact of network proximity to rail transit stations and on-street bike lanes and off-street multiuse paths. They confirmed Krizek's [33] finding that off-street facilities tend to appreciate property prices, while on-street bike lanes have the opposite effect. Li and Joh [34] found the impact of bike trails varies depending on the types of properties. The prices of condominium buildings increased with a greater rate than single-family houses in response to the bicycle accessibility, even though all the residential property values in Austin, Texas, had a positive relationship with the bicycle facilities. Other success stories of repurposing abandoned railroad into trails include the High Line, an elevated linear park in New York City. Originally developed as an elevated railroad in the 1930s [40], the first section of the High Line opened in 2009 to the public. Today, it is viewed as "one of the most thoughtful, sensitively designed public spaces built in New York in years" [41]. Other rail-to-trail conversions in rust belt cities are underway. Philadelphia has completed its first section of the Rail Park, which consists of a quarter mile of abandoned railroad transformed into pathways, green space, and bench swings with amazing city views [42]. In Cincinnati, the first section of the 7.6 mile long Wasson Way, a mixed-use trail running through twelve of Cincinnati's neighborhoods and connecting to the Little Miami Scenic Trail, has been opened to the public in July 2018 [43].

As shown in the relevant literature, urban parks and green spaces also have a significant impact on property prices. Earlier studies by Correll et al. [44], Crompton [45] and Lutzenhiser and Netusil [46] all concluded that the closer properties were to parks and green spaces, the higher the positive amenity effect is. In a more recent study of the City of Cincinnati, OH, parks system, vom Hofe et al. [47] found a strong negative relationship between property values and distance to the nearest park and positive relationship between park size and property values. Interesting is also their finding that parks with build-out recreational facilities, such as play grounds, basketball courts, or swimming pools, do negatively impact home values. Lin et al. [48] found heavily frequented parks to have little or even negative impacts on value. As such, more natural and less frequented parks have a greater positive impact on property values [49-51]. Espey and Owusu-Edusei [52] also see well-kept parks as the ones with the highest positive influence on property values. Lutzenhiser and Netusil [46] and Shultz and King [53] found that, when assessing their positive impacts, natural parks are preferred over smaller specialty parks with more intense recreational uses. Interestingly, some studies combined the effects on property values from trails and green spaces. Asabere and Huffman [54] for this reason compare the impacts of trails, greenbelts, and trails with greenbelts in San Antonio, TX. The authors find stronger impacts from greenbelts than from trails, but estimated the highest impact on values for trails buffered with green spaces. In addition, Netusil et al. [36] concluded that the size of greenways, which include bike trails and a proportion of the tree canopy in the facilities, yields a positive effect on prices of the singlefamily homes in Portland, OR.

\section{Data and Descriptive Statistics}

To study the effects of the Little Miami Scenic Trail on residential property values, we merged data from multiple sources into one database, including data from: (1) the Hamilton County Auditor's website, (2) the Cincinnati Area Geographical Information System (CAGIS), (3) the Ohio Department of Public Safety, (4) the Ohio State Education Department, and (5) the U.S. Census Bureau. We used ArcGIS to create a buffer of 10,000 feet (3048 m) around each of the 23 trail heads and identified as many as 8822 single-family residential properties within our designated study area. In a next step, we calculated Euclidean distances to the trail and network distances to the nearest trail entrance point for all residential properties. Lindsey et al. [35] used a one mile buffer to identify properties along the Monon Trail in Indianapolis. Of interest for our study is their finding that trail users living further than $1 / 2$ mile from the trail are more likely to drive to the trail. Parent and vom Hofe [9] in an earlier study of the Little Miami Scenic Trail used network distances of up to 10,000 feet $(3048 \mathrm{~m})$. Trail usage increases when parking is provided at trail heads. For instance, in 2014, over 100,000 people entered the Little Miami Scenic Trail through the Loveland trail head, ${ }^{1}$ many of which drove by car to the trail head. Supported by earlier studies and the fact that many people drive to the trail, we argue that the influence of the Little Miami Scenic Trail on residential property values extends beyond those properties adjacent to the trail and chose to include all properties within a 10,000 feet

\footnotetext{
1 "Improvements coming for the Little Miami State Park" in The Cincinnati Enquirer May 132015 by Marika Lee. Available at: https://www.cincinnati.com/story/news/local/loveland/2015/05/13/ improvements-coming-little-miami-state-park/27241995/.
} 
(3048 m) buffer zone. As shown in Fig. 2, our study area includes only the 12 -mile $(19.31 \mathrm{~km})$ section of the Little Miami Scenic Trail within Hamilton County. Further, residential properties are not distributed evenly across our study area, with less expensive houses in Loveland (Northern section) and Mariemont (Southern section), while more expensive properties can be found in between the Indian Hills. ${ }^{2}$ We confirm the uneven distribution of residential properties with a large and statistically significant ( $p$ value $<0.001,6$-nearest neighbor weight matrix) Moran's $I$ of 0.692 , which exhibits strong spatial correlation with respect to home values.

In Table 1, we report the variable definitions as well as their summary statistics. There is still an ongoing debate on whether to use market values or sales prices as the dependent variable in hedonic analysis. For a more detailed discussion of the advantages and disadvantages of market values, we refer to Cotteleer and van Kooten [55] and vom Hofe et al. [47]. For this research, we decided to use market values as the dependent variable, as they are easier to come by, result in a larger sample size, and, as pointed out by Ventolo and Williams [56], market values should come close to actual sales prices for arm's length transactions. The Hamilton County Auditor defines market values as the most probable prices of the properties in an open and competitive market with a willing buyer and seller. ${ }^{3}$

Following closely the relevant literature on hedonic pricing analysis, we include three categories of explanatory variables in our study: structural property characteristics $(S)$, neighborhood characteristics $(N)$, and locational characteristics $(L)$. The structural characteristics include the lot size of the property (numacres), the total square footage of the building (sqftinished), the number of bedrooms (bedrooms), the age of the building (age), the square of building age (agesquared), and the number of fireplaces (fireplace). In addition, the Hamilton County Auditor's office defines a building's condition as either very poor, poor, fair, average, good, very good, or excellent. We drop the "average" building condition (condaverage) from the list of explanatory variables and use it as our baseline to avoid multicollinearity. Accordingly, properties in below "average" condition (condverypoor, condpoor, condfair) should have lower market values, while properties in above "average" condition (condgood, condverygood, condexcellent) should have higher market values.

For this study, we include three neighborhood characteristics. We retrieved 2016 crime data from the Ohio

\footnotetext{
$\overline{2}$ Altogether, the rail-to-trail corridor runs through 12 jurisdictions: Anderson Township, City of Cincinnati, Columbia Township, Fairfax, Indian Hill, Loveland, Mariemont, Milford, Montgomery, Newtown, Symmes Township, and Terrace Park.

3 https://hamiltoncountyauditor.org/hamilton_glossary.
}

Department of Public Safety ${ }^{4}$ and calculated a jurisdictionspecific crime rate (crime) as the number of crimes/(population/1000) [57]. To account for differences in the quality of the school districts, we use Ohio Department of Education $^{5}$ school performance indicators (school; $\left.[18,58]\right)$. In addition, we include 2010 Census Bureau ${ }^{6}$ data to account for the percentage of residences holding a bachelor's degree (bachelor; [47]). While neighborhood characteristics are usually identical for neighboring properties, unless two neighboring properties are located in two different census tracts or jurisdictions, locational characteristics are different for all residential properties. A widely used locational measure in hedonic analysis is the Euclidean distance of a property to the central business district (CBD, [59]) to account for the price impact of access to the CBD. Adding Euclidean distances to the CBD also allows to properly identifying houses in space to avoid potential biases of the parameter estimates for park and trail distance variables [60]. Our trail corridor study area contains 23 parks, with an average size of 59.8 acres (24.2 hectares). In a recent study, vom Hofe et al. [47] found that proximity to assets of the City of Cincinnati park system has a major influence on single-family residential property values. For this reason, we also include two park-related variables in our study: the Euclidean distance to nearest park (distpark) and whether or not there is a park facility present in the nearest park (parkfacility), such as basketball, tennis, or soccer courts.

The main focus of this study is to evaluate the financial benefit single-family residential properties experience from proximity to the Little Miami Scenic Trail. Here, we assume that the positive spillover effects from the rail-totrail corridor originate from the fact that some trail users walk, bike, or drive their car to the closest trail entrance. Other residents perceive the trail as a pleasant amenity without making use of it. For this study, we account for either possibility and compare the results using both distance measures: network distances (disttrail_N) and Euclidean distances (disttrail_E). According to vom Hofe et al. [47], network distances account for the fact that residents walk, bike, or drive to the closest trail head, while Euclidean distances acknowledge resident's awareness of the trail as a recreational facility, without making use of it.

According to Table 1, we have as many as 8822 singlefamily residential properties included in our study. The average house ${ }^{7}$ in our study has a mean market value of

\footnotetext{
${ }^{4}$ Source: https://www.ocjs.ohio.gov/crime_stats_reports.stm.

${ }^{5}$ Source: http://reportcard.education.ohio.gov/Pages/default.aspx.

${ }^{6}$ Source: https://www.census.gov/en.html.

${ }^{7}$ We refer to the average house as the single-family residential property with all structural, neighborhood, and locational characteristics being the mean values represented in Table 1 . We will refer to
} 


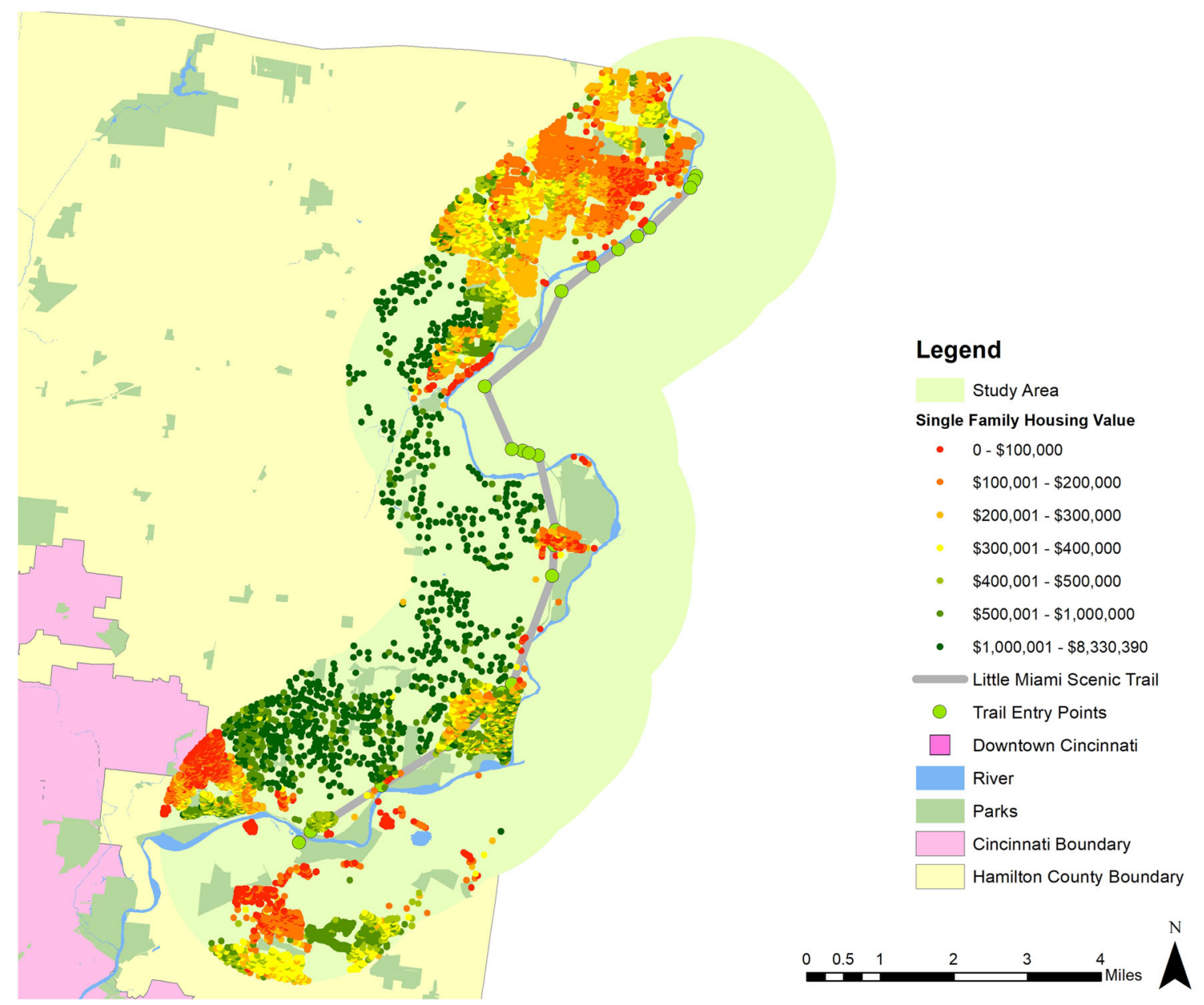

Fig. 2 Detailed map of the study area

$\$ 385,658$, which for the Cincinnati region is extremely high. For comparison, the mean market value reported by vom Hofe et al. [47] for a residential property in Cincinnati is $\$ 122,852$. Referring back to Fig. 2 above, we see that that a large section of our Little Miami Scenic Trail study area includes cities, such as Indian Hills, with property values in excess $\$ 1,000,000$. Our average house with a mean market value of $\$ 385,658$ is built on a 0.762 acres lot ( 0.308 hectares), has 2384 square feet (221 square meter) and 3.4 bedrooms. In addition, our average house is almost 54 years old and has approximately 1 fireplace. As one might expect for the study area, a majority of the houses are in either average condition (55.4\%) or good condition $(32.1 \%)$. Only very few properties are classified as either fair, poor, or very poor $(2.2 \%)$, while $10.4 \%$ are in above the "average" condition. With respect to the neighborhood characteristics, the average house is located in an area with a total of 20.8 crimes per 1000 residents, with an average

Footnote 7 continued

the average house repeatedly, when describing the marginal effects of our estimated parameters. school performance indicator of 102.3 , and where $58 \%$ of the population has at least a bachelor's degree. When considering the locational characteristics, we see that our average house is 12.7 miles $(20.44 \mathrm{~km})$ away from downtown Cincinnati. Considering the presence of as many as 23 parks in the study area, the average distance to the nearest park is only 1670 feet $(509 \mathrm{~m})$. Further, $41 \%$ of parks include some type of recreational facility. For this study, we calculated network and Euclidean distances between each residential property and its closest trail head. As expected, Euclidean distances are shorter with an average distance of 5846 feet $(1782 \mathrm{~m})$, while network distances average 7859 feet $(2395 \mathrm{~m})$.

\section{Model Specifications and Method of Analysis}

Recent years we have seen increases in the variety of spatial econometrics models used for hedonic pricing analysis. The appropriate framework selected based on particular interest for our study is the distinction made by 
Table 1 Variables: definitions and summary statistics $(n=8822)$

\begin{tabular}{|c|c|c|c|c|}
\hline Definition (abbreviations in parenthesis) & Mean & Median & Min & Max \\
\hline Market values of single-family residential properties (mktval) & $\$ 385,658$ & $\$ 239,750$ & $\$ 0$ & $\$ 8,330,390$ \\
\hline \multicolumn{5}{|l|}{ Structural characteristics $(S)$} \\
\hline Size of the land, in acres (numacres) & 0.762 & 0.345 & 0.000 & 20.680 \\
\hline Size of the building, in square feet (sqfinish) & 2383.951 & 2108.000 & 0.000 & $15,815.000$ \\
\hline Number of bedrooms (bedrooms) & 3.441 & 4.000 & 0.000 & 11.000 \\
\hline Age of the building, in years (age) & 53.829 & 50.000 & 9.000 & 216.000 \\
\hline Number of fireplaces in the building (fireplace) & 0.990 & 1.000 & 0.000 & 8.000 \\
\hline \multicolumn{5}{|l|}{ Condition of the house } \\
\hline Very poor (condverypoor) & 0.001 & 0.000 & 0.000 & 1.000 \\
\hline Poor (condpoor) & 0.003 & 0.000 & 0.000 & 1.000 \\
\hline Fair (condfair) & 0.018 & 0.000 & 0.000 & 1.000 \\
\hline Average (condaverage) & 0.554 & 1.000 & 0.000 & 1.000 \\
\hline Good (condgood) & 0.321 & 0.000 & 0.000 & 1.000 \\
\hline Very good (condverygood) & 0.096 & 0.000 & 0.000 & 1.000 \\
\hline Excellent (condexcellent) & 0.008 & 0.000 & 0.000 & 1.000 \\
\hline \multicolumn{5}{|l|}{ Neighborhood characteristics $(N)$} \\
\hline Crime rate (crime) & 20.840 & 13.407 & 8.000 & 155.000 \\
\hline Public school performance indicator (school) & 102.286 & 106.757 & 72.000 & 109.000 \\
\hline$\%$ of people with bachelor degree (bachelor) & 57.988 & 64.300 & 18.000 & 79.000 \\
\hline \multicolumn{5}{|l|}{ Locational characteristics $(L)$} \\
\hline Euclidean distance to Downtown Cincinnati (distcbd) & 12.666 & 13.293 & 7.147 & 18.484 \\
\hline Network distance from each property to nearest park (distpark) & 1669.624 & 1381.966 & 0.000 & 5769.000 \\
\hline Presence of park facility (parkfacility) & 0.410 & 0.000 & 0.000 & 1.000 \\
\hline Euclidean distance to trail entry, in feet (disttrail_E) & 5845.710 & 6152.000 & 0.000 & $10,183.000$ \\
\hline Network distance to trail entry, in feet (disttrail_N) & 7858.917 & 8105.119 & 0.000 & $30,336.000$ \\
\hline
\end{tabular}

LeSage [61] between local and global spatial spillovers. In hedonic pricing models, spatial spillovers exist in that the sales price of a single-family residential house is not only determined by its structural and neighborhood characteristics, but also by the sales prices and structural characteristics of residential properties that sold recently within close proximity of the house of interest. Applying Tobler's first law of geography_ “.... near things are more related than distant things" - to the real estate market implies that while nearby residential properties influence each other's sales prices, this influence vanishes with increasing distance between properties. The choice of the most appropriate spatial model variant has seen a lot of attention in the more recent spatial econometric literature. LeSage [61], for instance, argued to consider whether the spatial spillover effects are of local or global nature. Inspired by his argument and the fact that spatial spillover effects among residential properties are purely a local phenomenon, we selected two Bayesian spatial model variants, namely the spatial lag of X model (SLX) in (1) and the spatial Durbin error model (SDEM) in (2) as shown: $\ln (P)=\alpha+S \cdot \beta_{1}+W \cdot S \cdot \beta_{2}+N \cdot \beta_{3}+L \cdot \beta_{4}+\varepsilon$

$\ln (P)=\alpha+S \cdot \beta_{1}+W \cdot S \cdot \beta_{2}+N \cdot \beta_{3}+L \cdot \beta_{4}+u$

$u=\lambda \cdot W \cdot u+\varepsilon$

$\varepsilon \sim \operatorname{NID}\left(0, \sigma_{\varepsilon}^{2} I_{n}\right)$

where $\ln (P)$ is a vector of $\log$-transformed market values of single-family residential properties, $S$ is a matrix of structural house characteristics, $N$ is a matrix of neighborhood characteristics, $L$ is a matrix of locational characteristics, and $\beta_{1}, \beta_{2}, \beta_{3}$, and $\beta_{4}$ are the parameters to be estimated. The error terms $(\varepsilon)$ have the desired properties and as such are normally distributed, with a zero mean and a variance $\sigma_{\varepsilon}^{2}$. Both Bayesian model frameworks allow for local spillovers from neighboring residential properties, captured by the spatial lag term $W \cdot S$. For each property, we identify its 6-nearest neighbors by the spatial weight matrix $W$. As shown in (1) and (2), the local spillover effects $W \cdot S$ are identical in both spatial model variants. Having a weight 
matrix with zeros on the main diagonal also implies the absence of feedback effects, which makes the interpretation of the estimated $\beta_{1}$ and $\beta_{2}$ rather straightforward. The estimated coefficient $\beta_{1}$ refers to the effects of the own structural house characteristics $(S)$-i.e., the direct effects-while the estimated coefficient $\beta_{2}$ captures spatial spillovers for structural house characteristics from neighboring properties $(W \cdot S)$-i.e., the indirect effects. While both, the SLX and the SDEM model, account for local spatial spillover effects, they differ with respect to their error term structure. Specifically, the SDEM model uses a spatial specification for the error terms $(u=\lambda \cdot W \cdot u+\varepsilon)$, resembling global diffusion in the error term structure. Though the regression estimates from the SLX model should be unbiased, including the error terms $(u)$ in the SDEM model should increase the efficiency of the coefficient estimates. As in the SLX model, the errors from the disturbances $(\varepsilon)$ are normally distributed with a zero mean and a variance $\sigma_{\varepsilon}^{2}$ (see also [61], for a detailed discussion of the SLX and SDEM models). We selected a log-linear hedonic model due to its strong presence in the relevant literature [62] and to better control for the large variations in the market values. Altogether, we run two spatial model variants-the SLX model and the SDEM model-using both Euclidean and network distances in either model variant. We apply Bayesian estimation techniques to all presented models and correct for heteroscedastic disturbances following LeSage [63].

\section{Analysis and Discussion of Empirical Results}

The main focus of this study is to better understand the effects the Little Miami Scenic trail has on market values of single-family houses in the defined study area in Hamilton County, Ohio. Tables 2 and 3 summarize the regression results for the spatial lag of X model (SLX) and the spatial Durbin error model (SDEM) of each of our four econometric models. For reasons of comparison, we applied Euclidean distances [64] and network distances [9], calculated as the distances between a property and its closest trail entrance. Suggested by the relevant literature and supported by Fig. 2, we calculate the spatial correlation of home values and find a Moran's $I$ of 0.692 $(p<0.001)$, which confirms the presence of strong spatial correlation. The spatial coefficient $(\lambda)$ in both SDEM models is statistically significant at the $1 \%$ level with values of 0.659 and 0.656 when using Euclidean and network distances, respectively. We follow closely LeSage [63] and use a Bayesian estimation process, which corrects for heteroscedastic disturbances. We further eliminated some structural house characteristics (i.e., number of total bathrooms) from our list of explanatory variables to avoid multicollinearity problems as indicated by Variance Influence Factors (VIF) of greater than 5 [65]. After removing the number of bathrooms as an explanatory variable from our hedonic price models, the remaining VIF range from 1.006 to 2.616 indicating that no more multicollinearity is present.

Both SLX and SDEM models capture present direct and spillover effects. The parameter estimates $\beta_{1}, \beta_{3}$, and $\beta_{4}$ represent the direct effects originating from structural, neighborhood, and locational characteristics, respectively. The $\beta_{3}$ coefficients capture the spatial spillover effects from neighboring residential houses by means of their structural characteristics. The fact that the spatial weight matrix $(W)$ has zeros in the main diagonal cells and each row of $W$ sums to one makes the interpretation of the direct and indirect effects straightforward. Specifically, we can interpret the parameter estimates in Tables 2 and 3 as percentage changes in housing value following a unit change in the explanatory variables. The estimated coefficients $\beta_{1}, \beta_{2}, \beta_{3}$, and $\beta_{4}$ are unbiased for both models. We use the Akaike information criteria (AICs) for model comparison, where a smaller AIC indicates a better model fit [65]. Overall, we find that the two SLX models fit better to the data than the two SDEM models. The AICs for the SLX models are 6521.2 and 6521.8 when using Euclidean and network distances, respectively, and 6785.0 and 6788.6 for the two SDEM models. Interestingly, the difference for both spatial model variants becomes negligible when comparing the version using Euclidean distances to the version using network distances. All of the direct effect estimators of the Little Miami Scenic Trail are statistically significant at the $99 \%$ confidence level in the SLX models. On the other hand, in the SDEM model, the estimated parameters for the trail distance variable are only significant at the $90 \%$ confidence level when using Euclidean distances and not significant at all when using network distances. The presence of park facilities is significant at the 95\% confidence level in both SDEM models. Turning to the indirect effects, the SLX model results indicate that both spillover effects for $W *$ numacres and $W *$ condfair have the wrong sign and the $W *$ bedroom coefficient is not significant. Less favorable are the outcomes for the two SDEM models where half of the spillover effects appear not to be significant at the $95 \%$ confidence level (i.e., $W *$ bedrooms, $W *$ age, $W *$ agesquared, $W *$ condverypoor, $W *$ condfair, and $W *$ condexcellent). And again, the spillover effects for $W *$ numacres have the wrong sign.

Comparing the SLX and the SDEM frameworks with one another, we conclude that based on the lower AIC index, the SLX models are preferred over the SDEM models. Between the two SLX models reported in Table 2, the closeness of the AICs does not favor one model over 
Table 2 Effects of the bike trail and parks on the market values in the SLX model

\begin{tabular}{|c|c|c|c|c|c|}
\hline \multirow[t]{3}{*}{ SLX model } & \multicolumn{5}{|c|}{ Dependent variable: $m k t v a l$} \\
\hline & \multirow[t]{2}{*}{ Variable } & \multicolumn{2}{|c|}{ Euclidian distance } & \multicolumn{2}{|c|}{ Network distance } \\
\hline & & Coefficient & $p$ value & Coefficient & $p$ value \\
\hline \multirow[t]{13}{*}{ Structural characteristics $(S)$} & Constant & 10.8224 & $<0.01$ & 10.8285 & $<0.01$ \\
\hline & Numacres & 0.0555 & $<0.01$ & 0.0554 & $<0.01$ \\
\hline & Sqftfinished & 0.0002 & $<0.01$ & 0.0002 & $<0.01$ \\
\hline & Bedrooms & 0.0389 & $<0.01$ & 0.0389 & $<0.01$ \\
\hline & Age & -0.0132 & $<0.01$ & -0.0133 & $<0.01$ \\
\hline & Agesquared & 0.00006 & $<0.01$ & 0.00006 & $<0.01$ \\
\hline & Fireplace & 0.0828 & $<0.01$ & 0.0828 & $<0.01$ \\
\hline & Condverypoor & -0.7103 & $<0.01$ & -0.7198 & $<0.01$ \\
\hline & Condpoor & -0.6577 & $<0.01$ & -0.6612 & $<0.01$ \\
\hline & Condfair & -0.0933 & $<0.01$ & -0.0946 & $<0.01$ \\
\hline & Condgood & 0.0701 & $<0.01$ & 0.0702 & $<0.01$ \\
\hline & Condverygood & 0.1400 & $<0.01$ & 0.1430 & $<0.01$ \\
\hline & Condexcellent & 0.2413 & $<0.01$ & 0.2453 & $<0.01$ \\
\hline \multirow[t]{3}{*}{ Neighborhood characteristics $(N)$} & School & 0.0049 & $<0.01$ & 0.0049 & $<0.01$ \\
\hline & Bachelor & 0.0037 & $<0.01$ & 0.0037 & $<0.01$ \\
\hline & Crimerate & -0.0008 & $<0.01$ & -0.0009 & $<0.01$ \\
\hline \multirow[t]{4}{*}{ Locational characteristics $(L)$} & Distcbd & -0.0183 & $<0.01$ & -0.0176 & $<0.01$ \\
\hline & Distpark & -0.000017 & $<0.01$ & -0.000018 & $<0.01$ \\
\hline & Parkactive & 0.0410 & $<0.01$ & 0.0355 & $<0.01$ \\
\hline & Disttrail & -0.000004 & $<0.01$ & -0.000002 & $<0.01$ \\
\hline \multirow[t]{14}{*}{ Spatially lagged structure $(W)$} & $W *$ numacres & -0.1318 & $<0.01$ & -0.1319 & $<0.01$ \\
\hline & $W *$ sqftfinished & 0.0002 & $<0.01$ & 0.00019 & $<0.01$ \\
\hline & $W *$ bedrooms & -0.0055 & 0.274 & -0.0031 & 0.371 \\
\hline & $W *$ age & 0.0055 & $<0.01$ & 0.0052 & $<0.01$ \\
\hline & $W *$ agesquared & -0.00003 & $<0.01$ & -0.00003 & $<0.01$ \\
\hline & $W *$ fireplace & 0.2391 & $<0.01$ & 0.2374 & $<0.01$ \\
\hline & $W *$ condverypoor & -0.8622 & $<0.01$ & -0.8446 & $<0.01$ \\
\hline & $W *$ condpoor & -0.9765 & $<0.01$ & -0.9841 & $<0.01$ \\
\hline & $W *$ condfair & 0.0774 & 0.066 & 0.0831 & 0.048 \\
\hline & $W *$ condgood & 0.1362 & $<0.01$ & 0.1324 & $<0.01$ \\
\hline & $W *$ condverygood & 0.1740 & $<0.01$ & 0.1877 & $<0.01$ \\
\hline & $W *$ condexcellent & 0.2628 & $<0.01$ & 0.2685 & $<0.01$ \\
\hline & $R$-squared & 0.8907 & & 0.8909 & \\
\hline & AIC & 6521.2 & & 6521.8 & \\
\hline
\end{tabular}

the other, so that either model results-using Euclidean or network distances-would be valid. For the remainder of this section, we will rely on the SLX model results using network distances. The impacts of structural, neighborhood, and locational characteristics on the market values are all consistent prior expectations. Our average house in the study area has a market value of $\$ 383,571$ and is 7859 feet $(2395 \mathrm{~m})$ away from its closest trail entrance. As expected, the structural characteristics of houses considerably affect their values. Increasing the lot size by one acre adds $5.5 \%$ to a property's market value, which translates into $\$ 21,254$ for our average house valued at $\$ 383,571$. A one square foot (square meter) increase in building size is worth a $0.02 \%$ or $\$ 92(0.066 \%$ or $\$ 302)$ value increase and an additional bedroom a $3.9 \%(\$ 14,922)$ increase in value, both dollar values in parenthesis referring to our averagely priced house. Older houses decrease in value by $1.3 \%$ (\$5102); however, the age-specific annual rate of house value depreciation is $0.0058 \%$ as indicated by the positive agesquared coefficient. Given the large magnitude of the fireplace coefficient, i.e., 8.3\% (\$31,744), one must interpret its value added with extreme caution. Here, 
Table 3 Effects of the bike trail and parks on housing values in the SDEM

\begin{tabular}{|c|c|c|c|c|c|}
\hline \multirow[t]{3}{*}{ SDEM } & \multicolumn{5}{|c|}{ Dependent variable: $m k t v a l$} \\
\hline & \multirow[t]{2}{*}{ Variable } & \multicolumn{2}{|c|}{ Euclidian distance } & \multicolumn{2}{|c|}{ Network distance } \\
\hline & & Coefficient & $p$ value & Coefficient & $p$ value \\
\hline \multirow[t]{13}{*}{ Structural characteristics $(S)$} & Constant & 11.1711 & $<0.01$ & 11.1548 & $<0.01$ \\
\hline & Numacres & 0.0545 & $<0.01$ & 0.0543 & $<0.01$ \\
\hline & Sqftinished & 0.0002 & $<0.01$ & 0.0002 & $<0.01$ \\
\hline & Bedrooms & 0.0507 & $<0.01$ & 0.0508 & $<0.01$ \\
\hline & Age & -0.0126 & $<0.01$ & -0.0127 & $<0.01$ \\
\hline & Agesquared & 0.00005 & $<0.01$ & 0.00005 & $<0.01$ \\
\hline & Fireplace & 0.0671 & $<0.01$ & 0.0671 & $<0.01$ \\
\hline & Condverypoor & -0.6881 & $<0.01$ & -0.6875 & $<0.01$ \\
\hline & Condpoor & -0.6323 & $<0.01$ & -0.6325 & $<0.01$ \\
\hline & Condfair & -0.1460 & $<0.01$ & -0.1460 & $<0.01$ \\
\hline & Condgood & 0.0635 & $<0.01$ & 0.0635 & $<0.01$ \\
\hline & Condverygood & 0.1269 & $<0.01$ & 0.1282 & $<0.01$ \\
\hline & Condexcellent & 0.1670 & $<0.01$ & 0.1692 & $<0.01$ \\
\hline \multirow[t]{3}{*}{ Neighborhood characteristics $(N)$} & School & 0.0043 & $<0.01$ & 0.0043 & $<0.01$ \\
\hline & Bachelor & 0.0074 & $<0.01$ & 0.0074 & $<0.01$ \\
\hline & Crimerate & -0.0019 & $<0.01$ & -0.0019 & $<0.01$ \\
\hline \multirow[t]{4}{*}{ Locational characteristics $(L)$} & Distcbd & -0.0253 & $<0.01$ & -0.0245 & $<0.01$ \\
\hline & Distpark & -0.000017 & $<0.01$ & -0.000018 & $<0.01$ \\
\hline & Parkactive & 0.0375 & 0.016 & 0.0348 & 0.022 \\
\hline & Disttrail & -0.0000026 & 0.197 & -0.0000012 & 0.057 \\
\hline \multirow[t]{15}{*}{ Spatially lagged structure $(W)$} & $W *$ numacres & -0.0464 & $<0.01$ & -0.0473 & $<0.01$ \\
\hline & $W *$ sqftfinished & 0.0001 & $<0.01$ & 0.0001 & $<0.01$ \\
\hline & $W *$ bedrooms & 0.0197 & 0.073 & 0.0201 & 0.072 \\
\hline & $W * a g e$ & -0.0005 & 0.335 & -0.0006 & 0.312 \\
\hline & $W *$ agesquared & -0.00001 & 0.214 & -0.00001 & 0.241 \\
\hline & $W *$ fireplace & 0.1345 & $<0.01$ & 0.1345 & $<0.01$ \\
\hline & $W *$ condverypoor & -0.3052 & 0.159 & -0.3048 & 0.157 \\
\hline & $W *$ condpoor & -0.7992 & $<0.01$ & -0.8016 & $<0.01$ \\
\hline & $W *$ condfair & 0.0466 & 0.253 & 0.0494 & 0.241 \\
\hline & $W *$ condgood & 0.1188 & $<0.01$ & 0.1181 & $<0.01$ \\
\hline & $W *$ condverygood & 0.2412 & $<0.01$ & 0.2472 & $<0.01$ \\
\hline & $W *$ condexcellent & 0.1588 & 0.059 & 0.1609 & 0.061 \\
\hline & $\lambda$ & 0.6587 & $<0.01$ & 0.6564 & $<0.01$ \\
\hline & $R$-squared & 0.9291 & & 0.9291 & \\
\hline & AIC & 6785 & & 6788.6 & \\
\hline
\end{tabular}

we assert that the fireplace coefficient also serves as a proxy for other non-included structural characteristics, such as basement garage, heating, or air conditioning. The condition of a house is an important critical factor when determining its value. For this study, we use a total of seven distinct condition ratings (very poor, poor, average, good, very good, excellent), with very poor condition (condverypoor) being the worst, and excellent condition (condexcellent) being the best condition. To avoid perfect collinearity, we dropped the average house condition (condaverage) from our empirical models. As a result, the constant term of 10.822423 now represents a house in average condition, meaning that it contributes $e^{10.822423}=\$ 50,132$ to its values. Accordingly, houses in better than average condition are worth more and houses in worse than average condition are worth less. For instance, 
for a house to be in good condition adds $e^{10.892577}=\$ 53,776^{8}$ to its value. In other words, comparing a house in good condition is worth $\$ 3643$ more than a house in average condition. And houses in very good and in excellent condition are worth \$7706 and \$13,940 more, respectively. On the other hand, houses rated as being in lower-than-average condition have lower values. Specifically, they drop by $\$ 4526$ (fair) and $\$ 24,252$ (poor) and $\$ 25,725$ (very poor). While these condition numbers appear to be very marginal considering the mean house value being as high as $\$ 383,571$, one must remember that the house data indicate only very little variation with respect to the condition they are in. Of the 8822 properties in our sample, only $2.2 \%$ are rated below average and only $10.4 \%$ are rated as either very good or excellent. The SLX model contains lagged variables for the structural house characteristics to account for spatial spillover effects. Though these lagged explanatory variables address the presence of spatial correlation and help avoiding omitted variable bias [61], we abstain from interpreting them in greater detail. Comparing their estimated coefficients for all four model variants, we notice that they differ substantially between the SLX models and the SDEM models with respect to magnitude, direction, and significance. However, the only difference between the SLX and the SDEM variants is the added spatial disturbance structure in the error terms to improve efficiency. Without jumping to conclusions, we want to emphasize that both the Moran's I and the spatial coefficients $(\lambda)$ in the SDEM models are extremely high with values of greater than 0.65 (see also Fig. 2), which partially helps understanding the observed spatial spillover effects from neighboring residential properties.

Turning now to the neighborhood-related characteristics, we see a negative impact of crime on residential property values. Changing the crime rate by 1 unit leads to a drop of $0.5 \%$ or $\$ 1861$ in market value. Confirming prior expectations, houses in superior school districts and with a better education population, expressed as the percent of population holding a bachelor's degree, appreciate in value. Adding one point to the school district performance indicator increases home values by $0.4 \%$, or $\$ 1436$ of our averagely priced property, while a $1 \%$ change in residents holding a bachelor's degree is equivalent to a $0.09 \%$ (\$341) change in market value. The central business district (CBD) is the major location for consumption in metropolitan areas, and the proximity of a property to the CBD matters [12]. Our results confirm this theory as a mile increase in distance to the $\mathrm{CBD}$ reduces the value of a residential property by $1.7 \%$ or $\$ 6770$.

To address the presence of 23 parks in the study area, we follow a study by vom Hofe et al. [47] and include park

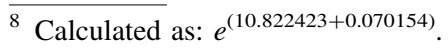

proximity and park facilities as control variables. As shown in studies by Correll et al. [44], Crompton [45], Espey and Owusu-Edusei [52], and Lutzenhiser and Netusil [46], urban parks do positively impact property values. In our study, moving a residential property one foot (meter) closer to its nearest park increases its value by $0.0018 \%$ or $\$ 6.90$ $(0.0059 \%$ or $\$ 22.64)$. Despite the fact that vom Hofe et al. [47] found a negative relationship between the presence of park facilities and house values, we conclude in this study that the presence of a recreational park facility adds as much as $3.6 \%(\$ 13,635)$ to the value of our average house. We explain this rather different finding by differences in the areas considered in the earlier study and the present study, such as the fact that all 23 parks included in our rail trail corridor are better maintained (as one would expect in neighborhoods with above average house values), which implies that they have a higher amenity value. Further, the larger average lot size of 0.762 acres (0.308 hectares) of properties in our rail trail corridor, compared to the City of Cincinnati average of 0.074 acres ( 0.030 hectares), means that residential properties are generally further away from recreational facilities so that noise does not become as much of an issue. Last, considering Nicholls and Crompton's [66] finding that the impact of recreational amenities vanishes beyond a $1 / 2$ mile $(800 \mathrm{~m})$ distance, implies that when using extended distance measures as we did in our study, any negative impact of recreational facilities can be outweighed by positive effects from houses that are further away.

With respect to the distance of residential properties to the Little Miami Scenic Trail, our results confirm that the Little Miami Scenic Trail generates a premium for houses that lies inside the 10,000 feet $(3048 \mathrm{~m})$ buffer around the rail trail. Using network distances, our SLX results show that decreasing the distance by 1 foot $(0.305 \mathrm{~m})$ appreciates property values by $0.00024 \%$. Taking a closer look at our average house prices at $\$ 383,571$, decreasing the distance by 1 foot $(0.305 \mathrm{~m})$ is equivalent to an increase in value of $\$ 0.92$ per foot (\$3.02 per meter). What appears to be only a marginal effect becomes quite significant, when one would compare our $\$ 383,571$ house that is 7859 feet $(2395 \mathrm{~m})$ away from its closest trail to exactly the same house adjacent to the trail. The house adjacent to the trail would be priced $1.89 \%$ (\$7238) higher.

Overall, our results confirm the positive effect of trails on residential property values reported in the literature, for example, by Li and Joh [34], Parent and vom Hofe [9], Asabere and Huffman [54], Lindsey et al. [35], and Nicholls and Crompton [66]. However, we find the effects of the Little Miami Scenic Trail to be somewhat smaller than the results reported in the literature for similar rail trails. We explain this as we allow for larger distances as reported in the studies mentioned above. With our sample 
properties being further away from the trail results ultimately in a smaller trail effect.

\section{Conclusion}

In this research, the Little Miami Scenic Trail has a significant impact on the market values of nearby homes, when distances to the nearest trail entrance are measured either as Euclidean or network distances. More specifically, by using network distances, results show that decreasing the distance by 1 foot $(0.305 \mathrm{~m})$ appreciates property values by $0.00024 \%$. For our average-priced house of $\$ 383,571$ in the rail trail corridor, decreasing the distance by 1 foot (meter) is equivalent to an increase in value of $\$ 0.92$ per foot (\$3.02 per meter). Keeping in mind that our average house is 7859 feet $(2395 \mathrm{~m})$ away from its closest trail head, the house would appreciate by $1.89 \%$ (\$7238) in value, when comparing it to exactly the same house adjacent to the Little Miami Scenic Trail.

The Little Miami Scenic Trail is a multi-purpose trail converted from an abandoned railroad corridor in southwestern Ohio. While there is a wide consensus among residents as well as policy makers that such a rail-to-trail conversion improves nearby residents quality of life, results presented here further estimate a significant appreciation of house values for properties in close proximity to a multi-purpose trail. The Monon Trail in Indianapolis, IN [35], and the bike path in Muskego, WI [30], are other examples of rail-to-trail conversions in the USA, where abandoned rail corridors now serve as multi-purpose trails. Similarly, the conversion of the freeway over the Cheong Gye Stream into an urban stream walkway in Seoul, Korea, also generated net benefits to residential land markets [38]. The results here confirm previous research on the economic benefits of converting obsolete transportation infrastructure into urban amenities, such as multi-purpose trails. While we have estimated the economic effects for private residential property owners, local governments in the USA also benefit by means of increased property tax revenues. Property taxes are a major revenue source for local governments in the USA [67, 68]. Though local governments face high costs for acquiring these abandoned rail corridors and transforming them into multi-purpose trails, they can transfer some of the initial costs to homeowners through the higher taxes they pay on the increase value of their property.

Rail-to-trail conversions also can be an effective landuse planning tool for utilizing obsolete railroad facilities outside the USA. In China, abandoned railroad corridors have been redeveloped for rapid transit [69] and urban heavy rail lines [70]. Further, with Beijing's bike-share programs having almost 1.2 million shared bikes, 11 million registered users, and daily ridership of 7 million people [71], the use of multi-purpose rail trails could enhance the flow of urban commuters by providing alternative routes for slow-traffic transportation modes, such as bicycling on the streets and road. In addition, an expanded network of multi-purpose trails would provide much needed recreational spaces, thereby improving the quality of life for many residents in Chinese cities. Since Chinese cities have relatively higher population and housing densities when compared to US cities [72], transforming abandoned Chinese railroad corridors into multi-purpose trails is likely to increase the values of nearby residential properties. With recent policy reforms regarding the property tax collection in Chinese cities [73], the potential increase in tax revenue associated with converting rail corridors into multi-purpose trails makes a strong argument for local governments to support plans, such as the Study of General Planning and Pilot Schemes for Recreational Trail Systems in Beijing. ${ }^{9}$

Open Access This article is distributed under the terms of the Creative Commons Attribution 4.0 International License (http://crea tivecommons.org/licenses/by/4.0/), which permits unrestricted use, distribution, and reproduction in any medium, provided you give appropriate credit to the original author(s) and the source, provide a link to the Creative Commons license, and indicate if changes were made.

\section{Compliance with Ethical Standards}

Conflict of interest This paper has no competing interests with any institutions or organizations.

\section{References}

1. Rails-to-Trails Conservancy (n.d.) What is a rail-trail? https:// www.railstotrails.org/build-trails/trail-building-toolbox/basics/ trail-building-basics/. Accessed 22 Oct 2018

2. Rovelli R, Senes G, Fumagalli N (2004) Ferrovie dismesse e greenways: Il recupero delle linee ferroviarie dismesse per la realizzazione di percorsi verdi. Associazione Italiana Greenways, Milan, p 132

3. Quattrone M, Tomaselli G, Demilio A, Russo P (2018) Analysis and evaluation of abandoned railways aimed at greenway conversion: a methodological application in the Sicilian landscape using multi-criteria analysis and GIS. J Agric Eng. https://doi.org/ 10.4081/jae.2018.744

4. China, Beijing Tourism Development Commission, Industrial Development Promotion Office (2015) Study of general planning \& pilot schemes for recreational trail systems in Beijing. http:// lyw.beijing.gov.cn/xxgk/ghjh/373221.htm. Accessed 22 Oct 2018

5. Yu Q, Lin S, Mo W (2013) The development and management of national scenic trails for America: take appalachian national scenic trail for example. Urban Plan Int 28(4):108-114

\footnotetext{
${ }^{9}$ For more information on the Study of General Planning and Pilot Schemes for Recreational Trail Systems in Beijing, please see: http:// lyw.beijing.gov.cn/xxgk/ghjh/373221.htm.
} 
6. Ding H, He J, Liu J (2017) A China-America comparative study of Beijing pedestrian system planning. Planners 2:98-103

7. Xu D, Guo J, Gao L (2014) The planning \& construction strategy and management \& maintenance mechanism of American greenway. Urban Plan Int 29(3):83-90

8. Qin X, Wei M (2013) The comparative study on the Chinese greenway and the American greenway. Chin Landsc Archit $4: 119-124$

9. Parent O, vom Hofe R (2013) Understanding the impact of trails on residential property values in the presence of spatial dependence. Ann Reg Sci 51:355-375. https://doi.org/10.1007/s00168012-0543-Z

10. Rail-Trail History (n.d.) https://www.traillink.com/trail-history/ little-miami-scenic-trail/. Retrieved 15 Oct 2018

11. Sorens J (2013) Public policy and quality of life: an empirical analysis of interstate migration, 2000-2012. SSRN Elec J. http:// dx.doi.org/10.2139/ssrn.2298744

12. Glaeser EL, Kolko J, Saiz A (2001) Consumer city. J Econ Geogr 1(1):27-50. https://doi.org/10.1093/jeg/1.1.27

13. Lancaster KJ (1966) A new approach to consumer theory. J Polit Econ 74(2):132-157

14. Rosen S (1974) Hedonic prices and implicit markets: product differentiation in pure competition. J Polit Econ 82(1):34-55

15. Li H, Wei YD, Yu Z, Tian G (2016) Amenity, accessibility and housing values in metropolitan USA: a study of Salt Lake County, Utah. Cities 59:113-125. https://doi.org/10.1016/j.cities. 2016.07.001

16. Nilsson P (2014) Natural amenities in urban space: a geographically weighted regression approach. Landsc Urban Plan 121:45-54. https://doi.org/10.1016/j.landurbplan.2013.08.017

17. Saphores JD, Li W (2012) Estimating the value of urban green areas: a hedonic pricing analysis of the single family housing market in Los Angeles, CA. Landsc Urban Plan 104:373-387. https://doi.org/10.1016/j.landurbplan.2011.11.012

18. Brasington D, Haurin DR (2006) Educational outcomes and house values: a test of the value added approach. J Reg Sci 46(2):245-268

19. La V (2015) Capitalization of school quality into housing prices: evidence from Boston Public School district walk zones. Econ Lett 134:102-106. https://doi.org/10.1016/j.econlet.2015.07.001

20. Hess DB, Almeida TM (2007) Impact of proximity to light rail rapid transit on station-area property values in Buffalo, New York. Urban Stud 44(5-6):1041-1068. https://doi.org/10.1080/ 00420980701256005

21. Martinez LM, Viegas JM (2009) Effects of transportation accessibility on residential property values hedonic price model in the Lisbon, Portugal, metropolitan area. Transp Res Rec 2115:127-137

22. Dv Dijk, Rosi S, Brouwer R, Logar I, Sanadgol D (2016) Valuing water resources in Switzerland using a hedonic price model. Water Resour Res 52:3510-3526. https://doi.org/10.1002/ 2015WR017534

23. Wen H, Xiao Y, Zhang L (2017) Spatial effect of river landscape on housing price: an empirical study on the Grand Canal in Hangzhou, China. Habitat Int 63:34-44. https://doi.org/10.1016/j. habitatint.2017.03.007

24. Kim S, Lee KO (2018) Potential crime risk and housing market responses. J Urban Econ 108:1-17. https://doi.org/10.1016/j.jue. 2018.09.001

25. Pope JC (2008) Fear of crime and housing prices: household reactions to sex offender registries. J Urban Econ 64:601-614. https://doi.org/10.1016/j.jue.2008.07.001

26. Hanninger K, Ma L, Timmings C (2017) The value of brownfield remediation. J Assoc Environ Resour Econ 4(1):197-241
27. Mihaescu O, vom Hofe R (2012) The impact of brownfields on residential property values in Cincinnati, Ohio: a spatial hedonic approach. J Reg Anal Policy 42(3):223-236

28. Park JH, Lee DK, Park C, Kim HG, Jung TY, Kim S (2017) Park accessibility impacts housing prices in Seoul. Sustainability 9(185):1-14. https://doi.org/10.3390/su9020185

29. Poudyal NC, Hodges DG, Bowker JM, Cordell HK (2009) Evaluating natural resource amenities in a human life expectancy production function. For Policy Econ 11:253-259. https://doi.org/ 10.1016/j.forpol.2009.04.007

30. Kashian R, Winden M, Storts E (2018) The effects of a recreational bike path on housing values in Muskego, Wisconsin. J Park Recreat Adm 36:160-173. https://doi.org/10.18666/JPRA2018-V36-I3-8509

31. Siedentopa S, Finab S, Krehl A (2016) Greenbelts in Germany's regional plans: an effective growth management policy? Landsc Urban Plan 145:71-82. https://doi.org/10.1016/j.landurbplan. 2015.09.002

32. Tekel A, Akbarishahabi L (2013) Determination of open-green space's effect on around house prices by means of hedonic price model; in example of Ankara/Botanik park. Gazi Univ J Sci 26(2):347-360

33. Krizek KJ (2006) Two approaches to valuing some of bicycle facilities' presumed benefits. J Am Plan Assoc 72(3):309-320

34. Li W, Joh K (2017) Exploring the synergistic economic benefit of enhancing neighbourhood bikeability and public transit accessibility based on real estate sale transactions. Urban Stud 54(15):3480-3499. https://doi.org/10.1177/0042098016680147

35. Lindsey G, Man J, Payton S, Dickson K (2004) Property values, recreation values, and urban greenways. J Park Recreat Adm 3:69-90

36. Netusil NR, Levina Z, Shandasb V, Hart T (2014) Valuing green infrastructure in Portland, Oregon. Landsc Urban Plan 124:14-21. https://doi.org/10.1016/j.landurbplan.2014.01.002

37. Welch T, Gehrke SR, Wang F (2016) Long-term impact of network access to bike facilities and public transit stations on housing sales prices in Portland, Oregon. J Transp Geogr 54:264-272. https://doi.org/10.1016/j.jtrangeo.2016.06.016

38. Kang CD, Cervero R (2009) From elevated freeway to urban greenway: land value impacts of the CGC project in Seoul, Korea. Urban Stud 46(13):2771-2794. https://doi.org/10.1177/ 0042098009345166

39. Ohler A, Blanco G (2017) Valuing public goods, the time to capitalization, and network externalities: a spatial hedonic regression analysis. Land Econ 93(1):127-144

40. Millington N (2015) From urban scar to 'park in the sky': terrain vague, urban design, and the remaking of New York City's High Line Park. Environ Plan A 47(11):2324-2338. https://doi.org/10. $1177 / 0308518 \times 15599294$

41. Ouroussoff N (2009) A walk on the high (and grassy) side: the high line. Retrieved from https://www.nytimes.com/2009/06/10/ arts/design/10high.html. Accessed 30 Nov 2018

42. De Groot K (2018) Elevated Philly rail park ready for 1st strolls. Retrieved from https://www.nbcphiladelphia.com/news/local/Phi ladelphia-Rail-Park-Elevated-Park-485064931.html. Accessed 30 Nov 2018

43. Wasson Way (n.d.) Wasson way. Retrieved 1 Dec 2018, from http://wassonway.org/

44. Correll MR, Lillydahl JH, Singell LD (1978) The effects of greenbelts on residential property values: some findings on the political economy of open space. Land Econ 54(2):207-217. https://doi.org/10.2307/3146234

45. Crompton JL (2001) The impact of parks on property values: a review of the empirical evidence. J Leisure Res 33(1):1-31. https://doi.org/10.1080/00222216.2001.11949928 
46. Lutzenhiser M, Netusil NR (2001) The effect of open spaces on a home's sale price. Contemp Econ Policy 19(3):291-298

47. vom Hofe R, Mihaescu O, Boorn ML (2018) Are homeowners willing to pay more for access to parks? Evidence from a spatial hedonic study of the Cincinnati, Ohio, USA park system. J Reg Anal Policy 48(3):66-82

48. Lin IH, Wu C, De Sousa C (2013) Examining the economic impact of park facilities on neighboring residential property values. Appl Geogr 45:322-331. https://doi.org/10.1016/j. apgeog.2013.10.003

49. Crompton JL (2004) The impact of parks and open space on property values and the property tax base. National Recreation \& Park Association, Ashburn

50. Anderson ST, West SE (2006) Open space, residential property values, and spatial context. Reg Sci Urban Econ 36(6):773-789. https://doi.org/10.1016/j.regsciurbeco.2006.03.007

51. Kong F, Yin H, Nakagoshi N (2007) Using GIS and landscape metrics in the hedonic price modeling of the amenity value of urban green space: a case study in Jinan City, China. Landsc Urban Plan 79(3-4):240-252. https://doi.org/10.1016/j.land urbplan.2006.02.013

52. Espey M, Owusu-Edusei K (2001) Neighborhood parks and residential property values in Greenville, South Carolina. J Agric Appl Econ 33(3):487-492. https://doi.org/10.1017/ S1074070800020952

53. Shultz SD, King DA (2001) The use of census data for hedonic price estimates of open-space amenities and land use. J Real Estate Finance Econ 22(2-3):239-252

54. Asabere PK, Huffman FE (2009) The relative impacts of trails and greenbelts on home price. J Real Estate Finance Econ 38:408-419

55. Cotteleer G, van Kooten GC (2012) Expert opinion versus actual transaction evidence in the valuation of non-market amenities. Econ Model 29(1):32-40

56. Ventolo WL, Williams MR (1994) Fundamentals of real estate appraisal. Dearborn Real Estate, Dearborn

57. Troy A, Grove JM (2008) Property values, parks, and crime: a hedonic analysis in Baltimore, MD. Landsc Urban Plan 87(3):233-245

58. Dougherty J, Harrelson J, Maloney L, Murphy D, Smith R, Snow M, Zannoni D (2009) School choice in suburbia: test scores, race, and housing markets. Am J Educ 115(4):523-548

59. Eiser RJ, Stafford T, Henneberry J, Catney P (2007) Risk perception and trust in the context of urban brownfields. Environ
Hazards 7(2):150-156. https://doi.org/10.1016/j.envhaz.2007.05. 004

60. Deaton BJ, Hoehn JP (2004) Hedonic analysis of hazardous waste sites in the presence of other urban disamenities. Environ Sci Policy 7(6):499-508

61. LeSage J (2014) What regional scientists need to know about spatial econometrics. Rev Reg Stud 44(1):13-32

62. Czembrowski P, Kronenberg J (2016) Hedonic pricing and different urban green space types and sizes: insights into the discussion on valuing ecosystem services. Landsc Urban Plan 146:11-19

63. LeSage JP (1999) Applied econometrics using MATLAB. University of Toledo Department of Economics, Toledo

64. Deza E, Deza MM (2009) Encyclopedia of distances. Springer, Berlin, p 94

65. Hadi AS (2007) Regression analysis by example. Wiley, New York, pp 287-288

66. Nicholls S, Crompton J (2005) The impact of greenways on property values: evidence from Austin, Texas. J Leisure Res 37(3):321-341

67. Kang SH, Skidmore M, Reese L (2015) The effects of changes in property tax rates and school spending on residential and business property value growth. Real Estate Econ 43(2):300-333. https://doi.org/10.1111/1540-6229.12077

68. Taylor C (2015) Property tax caps and citizen perceptions of local government service quality: evidence from the Hoosier survey. Am Rev Public Adm 45(5):525-541. https://doi.org/10.1177/ 0275074013516670

69. Wu X, Jiang L (2005) Making the disused railway lines as the city fast traffic track - taking the relocation of Yiwu section of Zhegan railway in its electrification as an example. Planners 21:43-46

70. Chen Y (2016) The extension of Nanjing Metro Line 8 and line 9 is not yet included in the new round of planning. Nanjing Morning Newspaper. http://js.ifeng.com/a/20161216/5236602_0. shtml. Accessed 26 Oct 2018

71. Deng L, Xie Y, Huang D (2017) Bicycle-sharing facility planning base on riding spatio-temporal data. Planners 10:82-88

72. Chen X (2003) Historical review of the USA urbanization and suburbanization process and future outlook of the Chinese urban development. Urban Plan Overseas 18(1):51-56

73. Zhang Z, Zuo Y (2018) NPC spokesman explained why the real estate tax law was accelerated. People.cn. http://house.people. com.cn/n1/2018/0305/c164220-29847486.html. Accessed 28 Oct 2018 